\title{
Can We Identify Macroscopic Texture of Coal under Microscopic Analysis Using Standard Petrographic Method?
}

\author{
Ferian Anggara ${ }^{* 1}$, Diyan Pamungkas ${ }^{2}$, and Wildan Guntur Prakoso ${ }^{2}$ \\ ${ }^{1}$ Department of Geological Engineering, Faculty of Engineering, Gadjah Mada University, Yogyakarta, Indonesia \\ ${ }^{2}$ Undergraduate Program, Department of Geological Engineering, Universitas Gadjah Mada
}

\begin{abstract}
Macroscopic texture in coals is not much getting attention to identify, because it is believed it doesn't hold much information about the coal characteristics. It is not true because some of important coal characteristics lie in its organic content which is reflected in its macroscopic texture (Moore, 2016). Conventional petrographic method using crushed sample cannot distinguish such feature microscopically, since the macroscopic texture will lose its integrity during the preparation. Petrographic analysis using block samples provide information about microscopic texture that can represents its macroscopic texture. Components in textural analysis are divided into three types based on the size, band (more than $800 \mu \mathrm{m})$, lens $(20-800 \mu \mathrm{m})$ and matrix (less than $20 \mu \mathrm{m})$. From the ratio between these three types of component and statistics, later it can be determined that nonbanded samples have less value of ratio between band and lens per matrix, and there will be a borderline between banded and non-banded samples based on the value. Banded texture in macroscopic feature consists of vitrain bands, and under microscope it can be identified as band and lens of macerals, while non-banded samples will mostly consist of matrix texture. Thus, it can be concluded that petrographic analysis using block samples can be used to identify microscopic texture representing the macroscopic texture, and can be proven through statistics as used in this research.
\end{abstract}

Keywords: Macroscopic texture $\cdot$ Macroscopic texture $\cdot$ Coal $\cdot$ Microscopic texture.

\section{INTRODUCTION}

In coal petrographic analysis, sample preparation standards like ASTM 2797 or ISO 7404-1 are commonly used. But using these conventional petrographic methods, we cannot see any characteristics that reflect its megascopic texture (Moore and Ferm, 1998). It is allegedly caused by the crushing coal to pass the 20 mesh or in the particle size smaller than $0.841 \mathrm{~mm}$ during the sample preparation. The crushed sample loses its megascopic texture significantly. Thus the information from the megascopic characteristic that could provide the percentage of the component microscopically is not able to observe (Moore and Hilbert, 1992), i.e., the loss

\footnotetext{
${ }^{*}$ Corresponding author: F. ANGGARA, Department of Geological Engineering, Gadjah Mada University. Jl. Grafika 2 Yogyakarta, Indonesia. E-mail: ferian@ugm.ac.id
}

of maceral percentage, telovitrinite subgroup which mostly composes band in banded bright texture (Moore and Ferm, 1998). Telovitrinite percentage decreasesto the most when it is destructed together with other components in a one mixed ply sample. This conditiong makesan inacurate reading on maceral percentage. There are several coal properties resulted from organic composition and reflected into macroscopic texture (Anggara et al., 2014; Beamish and Crosdale, 1998; Crosdale, 1995; Hower and Wild, 1994; Mares and Moore, 2008; Moore, 2012; Moore et al., 2002). Moore and Ferm (1988) proposed other analytical method providing better microscopic analysis, called block observation. This method is ablenot only to distinguish the size and shape of component, but also to determine the percentage between the component and the matrix. The aim of this paper is 
to compare the conventional method of petrographic analysis in Anggara et al., (2014) based on ASTM 2799-05a with proposed method by Moore and Ferm (1998). Within this method, we hope to see any significant difference between different megascopic texture banded or non-banded coal sample from the research area. The benefit of this study is the ability of the proposed analysis to assign more understanding about other aspect of coal characteristics that later determines both physical and chemical properties of the coal.

\section{Regional SETting}

Kutai Basin, mostly located in East Kalimantan, is the largest (covers around 165,000 $\mathrm{km}^{2}$ ) and the deepest (contains up to $12,000 \mathrm{~m}^{3}$ of sediments) tertiary basin in Indonesia (Satyana and Biantoro, 1995). It is bordered to the south by the Paternoster Platform and the Adang flexure zone, to the north by the Mangkalihat Ridge and, to the west, by the Kuching High, the source for most of the Neogene sediments. To the east, it extends to the deep waters of the Makassar Strait.

One of coal-bearing formations of Kutai Basin developed in the Middle Miocene age is Balikpapan Formation. The sequence of Balikpapan Formation consists of intercalated mudstone, siltstone, sandstone and coal seams (Macmillan et al., 2000). The coal sample was collected in this formation (Figure 1). Sequence succession of this formation was deposited in delta plain environment (Paterson et al., 1997).

\section{SAMPles AND METHODS}

\subsection{Samples}

Similar coal samples used in Anggara et al (2014) were chosen to conduct this study. Coals are sub-bituminous in rank with bright-banded lithotype and lignite with dull non-banded lithotype (Figure 1). The samples were collected from several wells' coring with various depths from 35 to 135 meters below the surface. These two coal lithotypes have different swelling properties and they are controlled by each lithotype as mentioned by Anggara et al. (2014).

\subsection{Methods}

Maceral analysis done by Anggara et al. (2014) uses ASTM D2799-05a as the standard. For microscopic texture observation, the samples were prepared using method that was submitted by Moore and Ferm (1988) in which block samples with dimension $5.5 \times 3 \times 2.5 \mathrm{~cm}$ was applied and the preparation considered the orientation of bands in the samples with banded lithotype.

Petrographic method proposed by Moore and Ferm (1988) uses sample that is blockshaped and mounted on epoxy-resin. The orientation of mounted samples considered the orientation of bands in the samples with banded lithotype. The samples were etched on surface at the right angles to bedding. After being polished, the samples were analyzed with point counting method, with 500 points counted for each samples or minimum 125 points based on Moore (2016). Magnification used in this method was $10 \times$ for objective lens without using immersion oil.

\section{Results AND Discussion}

\subsection{Maceral composition}

Maceral analysis shows no significant difference on each subgroup macerals for each sample. The maceral group composition of both banded and non-banded samples is nearly identical for each sample. Table 1 shows the maceral composition of coal sample dominated by huminite (80-84\%), liptinite (6-9\%) and inertinite (7-12\%) (Anggara et al., 2017). Minerals are also found in small amounts (0.7-3.6 \%) such as pyrite and clay.

Theoretically, banded coal has higher telohuminite sub-group than non-banded sample. From this basic theory, it can be concluded that result of maceral analysis can also reflect the macroscopic texture of the coal. Howeveras it is presented in Table 1, samples that macroscopically are identified as banded have lower telohuminite subgroup percentage in comparison to that of non-banded samples. The highest telohuminite percentage is identified in nonbanded sample NB1 with $42 \%$, while banded samples shows from around $19 \%$ to $22 \%$. The highest telohuminite percentage in banded sample presents in sample B1 with $28 \%$. This different result, which is significantly problematic, is caused by both banded and non-banded 


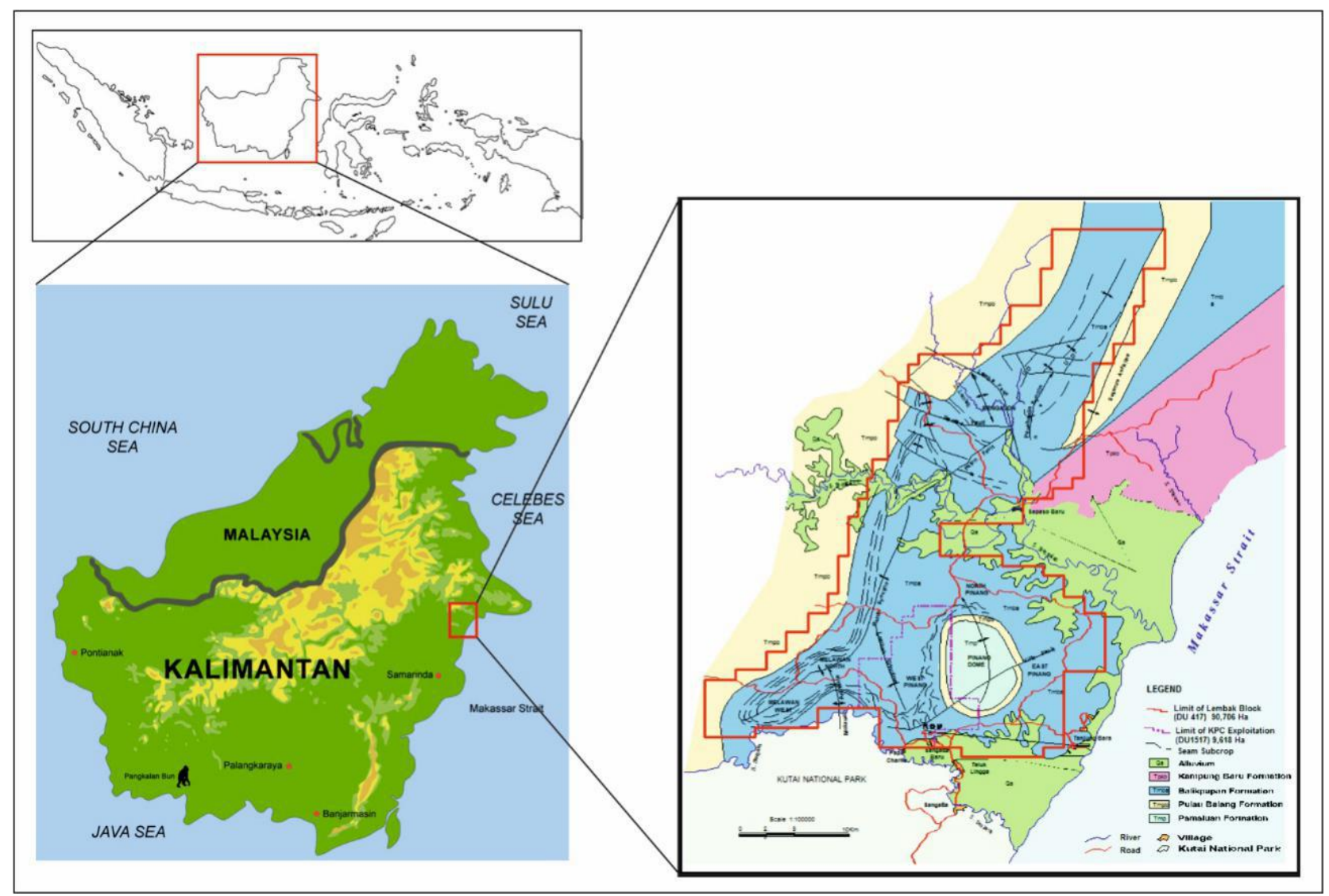

Figure 1. Location of this research where samples are collected (Macmillan, 2000).

coal types differ only in vitrain band size rather than total vitrain content (Moore and Ferm, 1988). Crushing method certainly make coals with larger size of vitrain bands losing their vitrain band-like characteristic. Therefore, maceral analysis from pellet method cannot be used to identify megascopic texture from coals.

\subsection{Macroscopic texture}

Classification of macroscopic texture for samples used in this research is using classification from Moore and Ferm (1992) because other classifications are applicable for coals with age from Carboniferous while Indonesian coals are mostly formed during Paleogene - Neogene (Moore and Ferm, 1992). Therefore, the classification from Moore and Ferm (1992) which was developed from the luster of coal and percentage of vitrain bands as the basis is used.

The samples are classified into two groups of megascopic textures, which are dull luster without bands and bright luster with bands. The proportion of vitrain bands in the banded samples is less than $30 \%$, meanwhile in the nonbanded samples it can be ignored (Anggara et al., 2014). Percentage of maceral group compo- sition for each sample is not drastically different as presented in Table 1. Difference of huminite reflectance for each sample can be seen in Figure 2. Higher huminite reflectance shows brighter color and alteration of maceral components becomes clearer. Hence, the difference of luster among samples is solely due to different rank of coal caused by different stage of coalification. Bright banded samples have higher rank than dull non-banded samples with subbituminous and lignite rank coal respectively.

\subsection{Microscopic texture}

Textural composition of the coal can be observed during the petrographic evaluation from the block sample. The texture can be divided into three groups based on the size of the components, which are band (more than $800 \mu \mathrm{m}$ ), lens $(20-800 \mu \mathrm{m})$ and matrix (less than $20 \mu \mathrm{m})$. From these three classifications, it can be statistically calculated and determined whether a sample of coal is banded or non-banded based from the block sample analysis. Coal with banded lithotype has more band textures than coal with non-banded lithotype that is mostly composed of matrix-sized components. Mathe- 
Table 1. Coal lithotype and maceral analysis of samples by Anggara et al. (2014).

\begin{tabular}{|c|c|c|c|c|c|c|c|c|c|c|}
\hline \multirow{2}{*}{$\begin{array}{l}\text { Sample } \\
\text { Group }\end{array}$} & & & & & & & & & & \\
\hline & \multicolumn{4}{|l|}{ Group I } & \multicolumn{6}{|c|}{ Group II } \\
\hline $\begin{array}{l}\text { Megascopic } \\
\text { texture }\end{array}$ & \multicolumn{4}{|c|}{ Dull luster, non-banded } & \multicolumn{6}{|c|}{ Bright luster, banded } \\
\hline Rank & \multicolumn{4}{|l|}{ Lignite* $^{*}$} & \multicolumn{6}{|c|}{ Sub-bituminous $A^{*}$} \\
\hline $\begin{array}{l}\text { Depth } \\
\text { interval (m) }\end{array}$ & $\begin{array}{l}100.56- \\
101.93\end{array}$ & $\begin{array}{l}101.94- \\
103.68\end{array}$ & $\begin{array}{l}121.75- \\
122.80\end{array}$ & $\begin{array}{l}122.81- \\
125.05\end{array}$ & $\begin{array}{l}34.25- \\
35.95\end{array}$ & $\begin{array}{l}57.10- \\
58.40\end{array}$ & $\begin{array}{c}58.41- \\
60.05\end{array}$ & $\begin{array}{l}108.06- \\
110.05\end{array}$ & $\begin{array}{c}133.80- \\
135.60\end{array}$ & $\begin{array}{l}135.61- \\
137.45\end{array}$ \\
\hline $\begin{array}{l}\text { Sample } \\
\text { code }\end{array}$ & NB01 & NB02 & NB03 & NB04 & B01 & B02 & B03 & B04 & B05 & B06 \\
\hline \multicolumn{11}{|l|}{$\begin{array}{l}\text { Petrographic } \\
\text { composition }\end{array}$} \\
\hline textinite & 1.4 & 1.0 & 0.6 & 0.4 & 2.2 & 1.4 & 0.2 & 1.4 & 0.4 & 0.4 \\
\hline ulminite & 41.0 & 28.6 & 21.8 & 23.4 & 26.0 & 18.0 & 23.4 & 23.0 & 18.6 & 19.0 \\
\hline $\begin{array}{l}\text { Total } \\
\text { telohuminite }\end{array}$ & 42.4 & 29.6 & 22.4 & 23.8 & 28.2 & 19.4 & 23.6 & 24.4 & 19.0 & 19.4 \\
\hline attrinite & 10.6 & 12.4 & 13.0 & 17.0 & 14.4 & 19.0 & 10.6 & 4.8 & 14.4 & 17.4 \\
\hline densinite & 7.0 & 8.4 & 10.0 & 11.4 & 13.8 & 7.3 & 9.2 & 11.8 & 16.0 & 8.8 \\
\hline $\begin{array}{l}\text { Total detro- } \\
\text { huminite }\end{array}$ & 17.6 & 20.8 & 23 & 28.4 & 28.2 & 26.3 & 19.8 & 16.6 & 30.4 & 26.2 \\
\hline corpohuminite & 17.0 & 22.2 & 21.0 & 19.0 & 13.1 & 27.8 & 26.4 & 30.0 & 18.2 & 27.6 \\
\hline gelinite & 6.8 & 10.4 & 15 & 9.0 & 12.5 & 6.1 & 13.6 & 9.8 & 12.2 & 8.2 \\
\hline $\begin{array}{l}\text { Total } \\
\text { gelohuminite }\end{array}$ & 23.8 & 32.6 & 36 & 28.0 & 25.6 & 33.9 & 40.0 & 39.8 & 30.4 & 35.8 \\
\hline$\frac{\text { Total }}{\text { huminite }}$ & $\underline{83.8}$ & $\underline{83}$ & $\underline{81.4}$ & $\underline{80.2}$ & $\underline{82.0}$ & $\underline{79.6}$ & 83.4 & $\underline{80.8}$ & 79.8 & 81.4 \\
\hline$\overline{\text { fusinite }}$ & 1.2 & 0.8 & 0.0 & 0.8 & 2.4 & 0.8 & 0.0 & 0.2 & 0.8 & 0.4 \\
\hline semifusinite & 1.4 & 0.8 & 2.4 & 1.4 & 2.0 & 1.8 & 1.4 & 2.8 & 4.0 & 1.8 \\
\hline funginite & 1.2 & 3.2 & 2.2 & 3 & 1.8 & 2.2 & 2.0 & 2.4 & 2.4 & 3.2 \\
\hline secretinite & 0.0 & 0.0 & 0.0 & 0.0 & 0.0 & 0.0 & 0.0 & 0.0 & 0.0 & 0.0 \\
\hline macrinite & 0.4 & 0.4 & 0.2 & 0.0 & 1.3 & 0.2 & 0.2 & 0.0 & 0.8 & 0.6 \\
\hline micrinite & 0.8 & 0.6 & 1.0 & 0.2 & 0.0 & 2.5 & 0.4 & 1.4 & 0.0 & 0.6 \\
\hline inertodetrinite & 2.0 & 2.4 & 3.8 & 3.4 & 3.1 & 3.1 & 2.6 & 2.6 & 4.2 & 3.2 \\
\hline$\frac{\text { Total }}{\text { inertinite }}$ & $\underline{7.0}$ & $\underline{8.2}$ & $\underline{9.6}$ & $\underline{8.8}$ & $\underline{10.5}$ & $\underline{10.6}$ & $\underline{6.6}$ & $\underline{9.4}$ & 12.2 & 9.8 \\
\hline$\overline{\text { sporinite }}$ & 0.0 & 0.2 & 0.4 & 0.4 & 0.5 & 0.0 & 0.0 & 0.4 & 0.4 & 0.0 \\
\hline cutinite & 2.8 & 3.0 & 2.0 & 4.0 & 1.6 & 1.2 & 2.0 & 1.6 & 2.4 & 2.8 \\
\hline resinite & 1.4 & 0.4 & 0.6 & 1.0 & 1.3 & 2.0 & 1.0 & 1.4 & 1.2 & 1.2 \\
\hline alginite & 0.0 & 0.0 & 0.0 & 0.0 & 0.0 & 0.0 & 0.0 & 0.0 & 0.0 & 0.0 \\
\hline liptodetrinite & 1.4 & 1.6 & 1.4 & 1.2 & 2.0 & 2.4 & 1.6 & 1.2 & 0.2 & 1.0 \\
\hline suberinite & 1.2 & 1.4 & 1.2 & 1.0 & 0.9 & 2.2 & 3.2 & 1.2 & 2.2 & 2.2 \\
\hline $\begin{array}{l}\text { chlorophyl- } \\
\text { linite }\end{array}$ & 0.0 & 0.0 & 0.0 & 0.0 & 0.0 & 0.0 & 0.0 & 0.0 & 0.0 & 0.0 \\
\hline exsudatinite & 0.6 & 0.0 & 0.8 & 0.6 & 0.4 & 0.4 & 0.2 & 0.4 & 0.4 & 0.2 \\
\hline bituminite & 0.0 & 0.0 & 0.0 & 0.0 & 0.0 & 0.0 & 0.0 & 0.0 & 0.0 & 0.0 \\
\hline fluorinite & 0.0 & 0.0 & 0.2 & 0.4 & 0.0 & 0.0 & 0.0 & 0.0 & 0.0 & 0.0 \\
\hline$\frac{\text { Total }}{\text { liptinite }}$ & $\underline{7.4}$ & $\underline{6.6}$ & $\underline{6.6}$ & $\underline{8.6}$ & $\underline{6.7}$ & $\underline{8.0}$ & $\underline{8.0}$ & $\underline{6.2}$ & $\underline{6.8}$ & $\underline{7.4}$ \\
\hline$\frac{\text { Mineral }}{\text { matter }}$ & $\underline{1.8}$ & $\underline{2.2}$ & $\underline{2.4}$ & $\underline{2.4}$ & $\underline{0.7}$ & $\underline{1.8}$ & $\underline{2.0}$ & $\underline{3.6}$ & $\underline{1.2}$ & $\underline{1.4}$ \\
\hline $\begin{array}{l}\text { Huminite } \\
\text { reflectance } \\
\end{array}$ & $\underline{0.37}$ & $\underline{0.38}$ & $\underline{0.37}$ & $\underline{0.37}$ & $\underline{0.47}$ & $\underline{0.47}$ & $\underline{0.47}$ & $\underline{0.46}$ & $\underline{0.50}$ & $\underline{0.50}$ \\
\hline
\end{tabular}




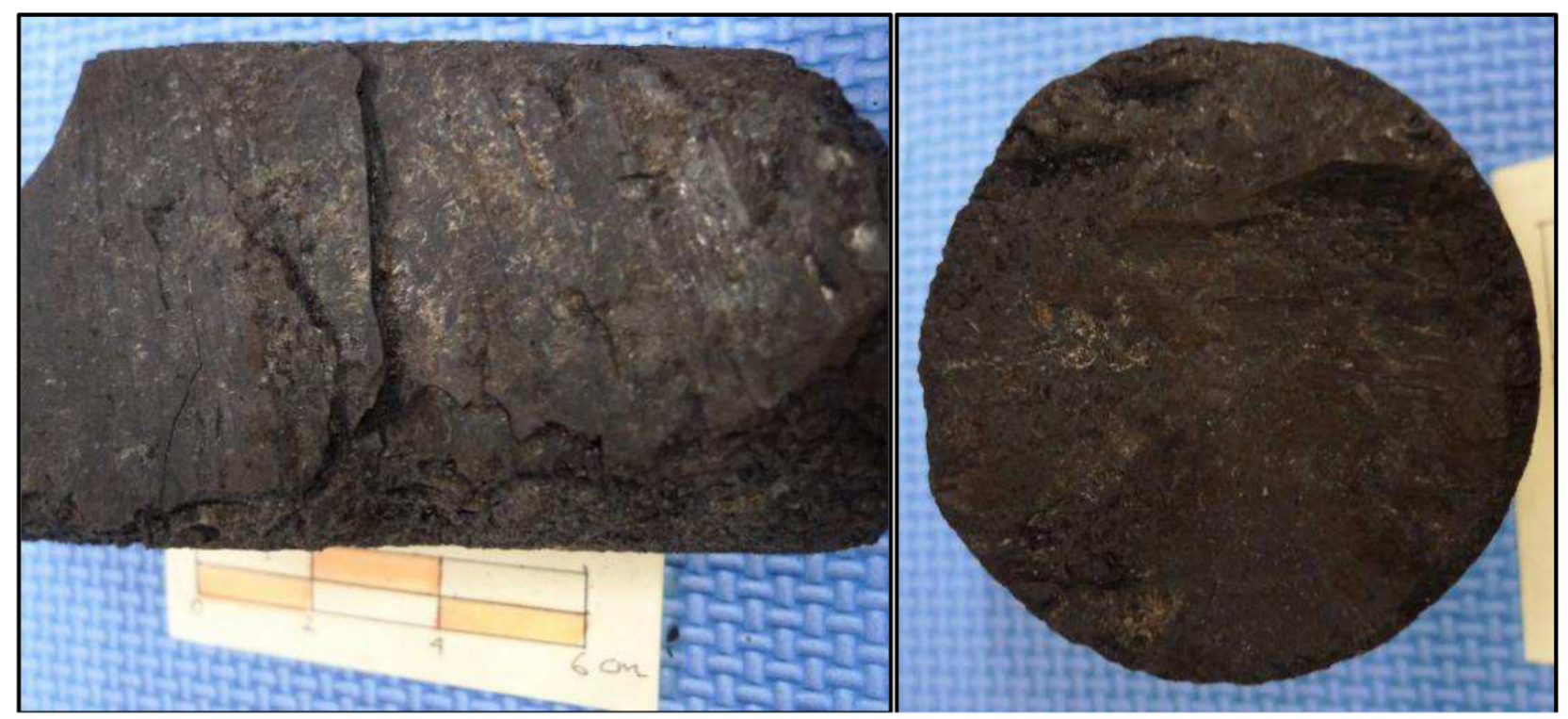

Figure 2. Example of samples used, bright-banded coal (left) and dull non-banded coal (right).

matically, it is expressed as a formula consisting of percentage of bands and/or lenses per percentage of matrix. The result of the block sample analysis is presented in Table 2.

Generally, all samples of both non-banded and banded coals have matrix percentage higher than band and lens components. Sample B6 has smaller difference in both matrix and band percentages compared to others (49\% and $43 \%$ ) respectively. The highest difference is observed in sample NB3 in which the percentage of matrix and band texture is $71 \%$ and $9 \%$ respectively. In the non-banded lithotype, samples obviously show larger percentage of matrix and smaller percentage of band component, because the band texture has smaller percentage in volume although the bands are hardly distinguished in macroscopic observation (Figure 3). Because of this, later in the result of ratio between banded and/or lens with matrix percentage will show variance, from the lowest (sample NB3) to the highest ratio (sample B6). The result from ratio between band and lens components with matrix percentage shows almost the same value with the result from band vs. matrix. Different case is presented in the lens and matrix texture ratio in which the results are more scattered and show no trend. Forementioned, the result of non-banded sample NB4 has similar value with banded sample B4 and B6 with 0.17, 0.16 and 0.14 respectively. The same case occurs in non-banded sample NB1 with banded samples B5, B2 and B7 with
$0.20,0.23,0.21$ and 0.20 respectively, although the ratio of sample NB1 has the exact same value with sample B7. This is different from the result ofmatrix - band percentage ratio and matrix - band plus lens ratio in which shows trend. The result albeit scattered yet still can be separated into groups to be differentiated. Thus, the result of matrix - lens percentage ratio cannot be used to differentiate samples with banded and non-banded lithotype. After that, the result from matrix - band and matrix band plus lens ratio was plotted in Figure 4.

Figure 4 shows that the matrix and band percentage ratio from banded and non-banded samples is scattered. Moreover it reveals the existence of what so called the border which is certain number separating resulted groups. The number can be determined from the median between the highest ratio resulted from the nonbanded samples and the lowest resulted from the banded samples (which are 0.35 and 0.45 respectively) by applying statistical method. Thus, it can be calculated that the limit number between banded and non-banded samples is 0.4 . It also shows the same pattern onthe matrix - band ratio.Using the same method, it can be calculated that the limit number of banded and non-banded samples is 0.565 . The limit number for band-matrix ratio or band plus lensmatrix percentage ratio to differentiate banded and non-banded lithotype could not be generelized for any coal samples. Aside from the difference, the result of matrix-band percent- 
Table 2. Percentage of microscopic texture and the ratio between each texture.

\begin{tabular}{|c|c|c|c|c|c|c|}
\hline & Band (\%) & Lens (\%) & Matrix (\%) & $\begin{array}{l}\text { Band/ } \\
\text { matrix }\end{array}$ & $\begin{array}{l}\text { Lens/ } \\
\text { matrix }\end{array}$ & $\begin{array}{c}\text { Band+lens/ } \\
\text { matrix }\end{array}$ \\
\hline \multicolumn{7}{|c|}{ Non-banded samples } \\
\hline NB01 & 22 & 13 & 65 & 0.34 & 0.20 & 0.54 \\
\hline NB02 & 9 & 20 & 71 & 0.13 & 0.28 & 0.41 \\
\hline NB03 & 23 & 11 & 66 & 0.35 & 0.17 & 0.52 \\
\hline \multicolumn{7}{|c|}{ Banded samples } \\
\hline B01 & 38 & 15 & 47 & 0.81 & 0.32 & 1.13 \\
\hline B02 & 37 & 11 & 52 & 0.71 & 0.21 & 0.92 \\
\hline B03 & 24 & 23 & 53 & 0.45 & 0.43 & 0.89 \\
\hline B04 & 28 & 9 & 63 & 0.44 & 0.14 & 0.59 \\
\hline B05 & 36 & 12 & 52 & 0.69 & 0.23 & 0.92 \\
\hline B06 & 43 & 8 & 49 & 0.88 & 0.16 & 1.04 \\
\hline B07 & 29 & 12 & 59 & 0.49 & 0.20 & 0.69 \\
\hline
\end{tabular}
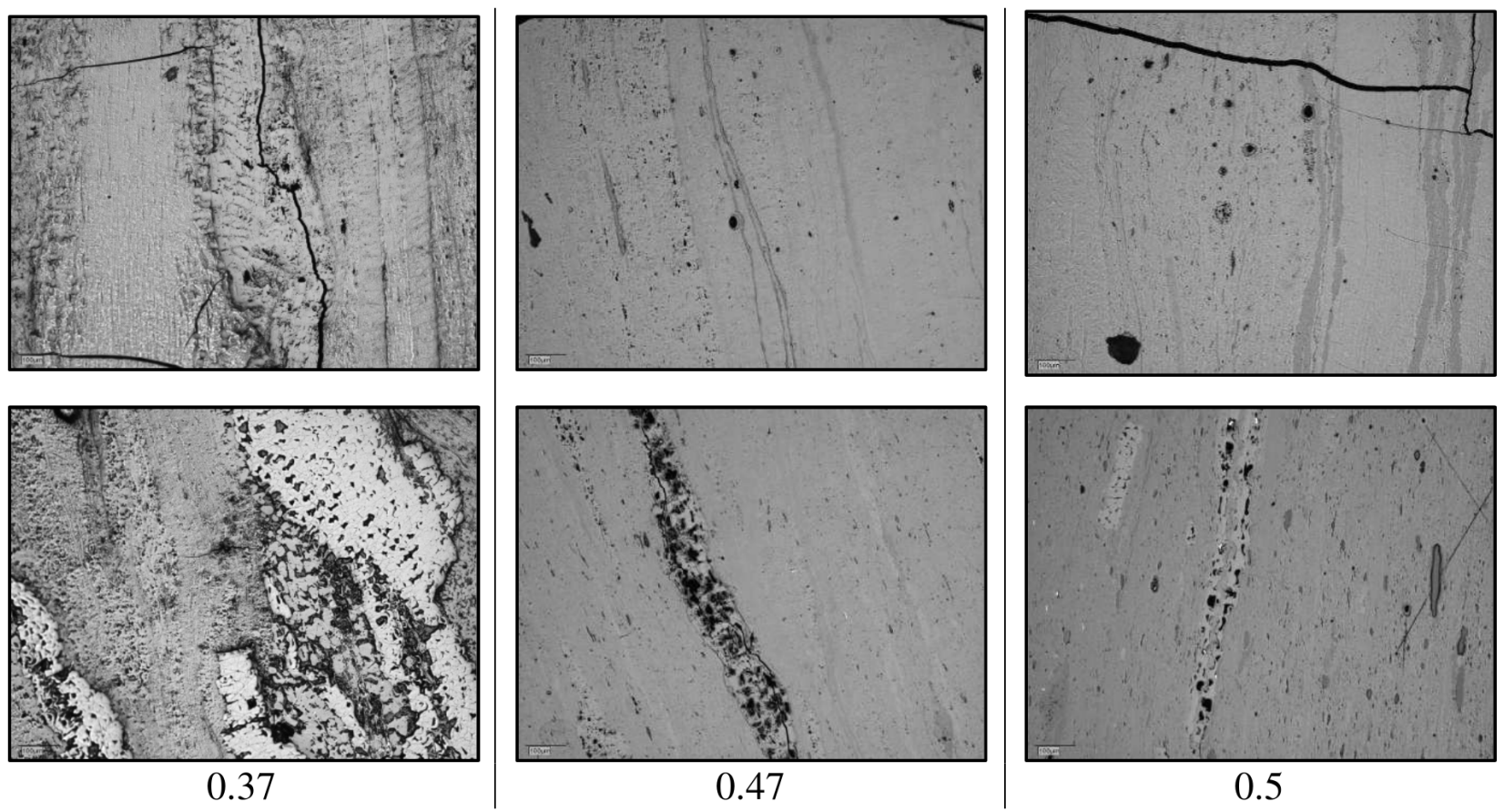

Figure 3. Petrographic appearance of samples with their respective huminite reflectance. 

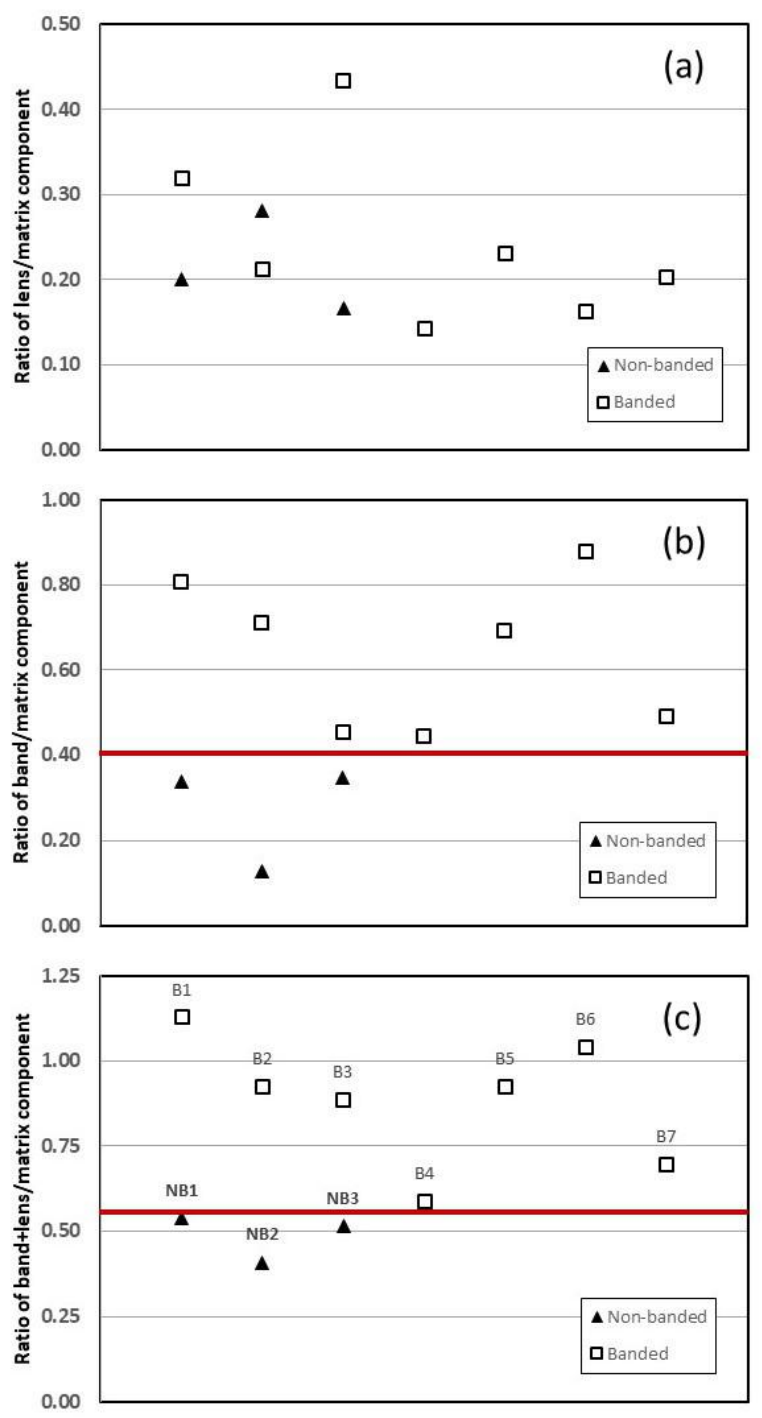

Figure 4. Ratio of (a) lens/matrix; (b) band/matrix; (c) band+lens/matrix component for Banded (B) and Non-Banded (NB) sample. The ratio shows significant different between Banded and Non-Banded sample for band/matrix as well as band+lens/matrix component.

age ratio remains the same that it can be separated into two groups of sample with banded and non-banded lithotypes only from the microscopic observation.

Banded and non-banded lithotypes in coal can be used as marking for maceral types based on the presence of bands. Using block samples, it can be justified that banded coals has high percentage of band-shaped macerals (i.e. telohuminite subgroup) while non-banded coals has matrix-shaped macerals (i.e. detrohuminite subgroup). Other maceral types such as cutinite, sporinite, resinite and funginite can also be found as matrix. Crushed-sample mac- eral analysis data has weakness on the inability to identify the megascopic feature from textural components. It is caused by the megascopic textures are recognized based from the presence of vitrain bands, not the maceral composition. Crushing method destroys vitrain bands into detrital, and the detrital is identified as smaller components. Block method provides solution for recognizing microscopic texture that is not represented on megascopic feature. Under microscope, the identification of maceral subgroup, i.e., telohuminite, gelohuminite and maceral group, i.e., inertinite and liptinite that has preserved tissues is in the form of smaller maceral type because it turns into detritus macerals. Thus comparing maceral data of both crushed and block samples is important. The comparison can be seen in Table 3 that explains data resulted from block sample as well as crushed sample data. From the crushed sample, telohuminite is in about the same percentage of banded and non-banded samples. The same results are also shown in other macerals, i.e. detrohuminite, funginite, sporinite and $\mathrm{cu}-$ tinite. Thus, block sample analysis helps identify banded and non-banded samples based on textural components. Microscopic texture such as band, lens and matrix can be analogized with maceral components. Band texture is comparable with telohuminite, while lens texture is comparable with detrohuminite, funginite, sporinite, inertodetrinite, cutinite, resinite and liptodetrinite. Furthermore matrix can be correlatedas gelohuminite. Banded and non-banded samples with band plus lens per matrix value as border point for banded of 0.5 gives the appropriate megascopic feature of the samples and the border point from band per matrix of 0.4 .

\section{CONCLUSION}

From this research, it can be concluded that the pellet method fails in identifying megascopic texture microscopically because macroscopic texture is distinguished by vitrain bands aside from the vitrain composition. By crushing the coals, vitrain bands lose its integrity as bands and crushed into smaller detrital that is identified under microscope as smaller components. Block method can solve this problem by observing block samples of coal under microscope. Using this method, it can be determined 
Table 3. Comparison between petrographic result from crushed samples and block samples.

\begin{tabular}{|c|c|c|c|c|c|c|c|c|c|c|c|}
\hline \multicolumn{12}{|c|}{ Crushed sample } \\
\hline $\begin{array}{l}\text { Microscopic } \\
\text { Texture }\end{array}$ & $\begin{array}{l}\text { Maceral } \\
\text { Equivalent }\end{array}$ & NB01 & NB02 & NB03 & B01 & B02 & B03 & B04 & B05 & B06 & B07 \\
\hline \multirow{4}{*}{ Band (\%) } & Telohuminite & 42.4 & 22.4 & 23.8 & 28.2 & 19.4 & 23.6 & 24.4 & 19.0 & 19.4 & 30.0 \\
\hline & Detrohuminite & 17.6 & 23 & 28.4 & 28.2 & 26.3 & 19.8 & 16.6 & 30.4 & 26.2 & 21.0 \\
\hline & Funginite & 1.2 & 2.2 & 3.0 & 1.8 & 2.2 & 2 & 2.4 & 2.4 & 3.2 & 3.0 \\
\hline & Inertodetrinite & 2.0 & 3.8 & 3.4 & 3.1 & 3.1 & 2.6 & 2.6 & 4.2 & 3.2 & 2.0 \\
\hline \multirow{4}{*}{ Lens (\%) } & Sporinite & 0.0 & 0.4 & 0.4 & 0.5 & 0.0 & 0.0 & 0.4 & 0.4 & 0.0 & 0.0 \\
\hline & Cutinite & 2.8 & 2.0 & 4.0 & 1.6 & 1.2 & 2.0 & 1.6 & 2.4 & 2.8 & 3.0 \\
\hline & Resinite & 1.4 & 0.6 & 1.0 & 1.3 & 2.0 & 1.0 & 1.4 & 1.2 & 1.2 & 0.0 \\
\hline & Liptodetrinite & 1.4 & 1.4 & 1.2 & 2.0 & 2.4 & 1.6 & 1.2 & 0.2 & 1.0 & 2.0 \\
\hline Matrix (\%) & Gelohuminite & 23.8 & 36.0 & 28.0 & 25.6 & 33.9 & 40.0 & 39.8 & 30.4 & 35.8 & 33.0 \\
\hline \multicolumn{12}{|c|}{ Block sample } \\
\hline \multicolumn{2}{|c|}{ Microscopic Texture } & NB01 & NB02 & NB03 & B01 & B02 & B03 & B04 & B05 & B06 & B07 \\
\hline \multicolumn{2}{|l|}{ Band (\%) } & 30.0 & 22 & 9 & 23 & 38 & 37 & 24 & 28 & 36 & 43 \\
\hline \multicolumn{2}{|l|}{ Lens (\%) } & 21.0 & 13 & 20 & 11 & 15 & 11 & 23 & 9 & 12 & 8 \\
\hline \multicolumn{2}{|l|}{ Matrix (\%) } & 3.0 & 65 & 71 & 66 & 47 & 52 & 53 & 63 & 52 & 49 \\
\hline \multicolumn{2}{|l|}{ Band/Matrix } & 2.0 & 0.34 & 0.13 & 0.35 & 0.81 & 0.71 & 0.45 & 0.44 & 0.69 & 0.88 \\
\hline \multicolumn{2}{|l|}{ Lens/Matrix } & 0.0 & 0.20 & 0.28 & 0.17 & 0.32 & 0.21 & 0.43 & 0.14 & 0.23 & 0.16 \\
\hline \multicolumn{2}{|c|}{ Band+Lens/Matrix } & 0.54 & 0.41 & 0.52 & 1.13 & 0.92 & 0.89 & 0.59 & 0.92 & 1.04 & 0.69 \\
\hline
\end{tabular}

the microscopic texture representing its macroscopic feature. This method can be proven statistically using numbers and formula. Despite of that, the calculation result may be different for sample used in the future research. By distinguishing different texture, it can be used as data to correlate with other coal characteristics.

\section{REFERENCES}

Anggara, F., Sasaki, K., Rodrigues, S., Sugai, Y. (2014) The effect of megascopic texture on swelling of a low rank coal in supercritical carbon dioxide, International Journal of Coal Geology 125, pp. 45-56.

Beamish, B.B. and Crosdale, P.J. (1998) Instantaneous outbursts in underground coal mines: An overview and association with coal type. International Journal of Coal Geology 35, p.27-55.

Crosdale, P.J. (1995) Lithotype sequences in the Early Miocene Maryville Coal Measures, New Zealand. International Journal of Coal Geology,28, pp.37-50. DOI: 10.1016/01665162(95)00003-V.

Hower, J.C. and Wild, G.D. (1994) Maceral/microlithotype analysis evaluation of coal grinding: examples from central Appalachian high volatile bituminous coals. Journal of Coal Quality, 13, pp.35-40.

Macmillan, S., Supatrisno, Sinulingga, R. (2000) Geology of Lembak Syncline, PT Kaltim Prima Coal,
Kalimantan Timur. Proceedings of Southeast Coal Geology Conference, Directorate General of Geology and Mineral Resources of Indonesia, pp. 59-67.

Mares, T.E. and Moore, T.A. (2008) The influence of macroscopic texture on biogenicallyderived coalbed methane, Huntly coalfield, New Zealand. International Journal of Coal Geology,76, pp. 175185. DOI: $10.1016 /$ j.coal.2008.05.013.

Moore, T.A. (2012) Coalbed methane: A review. International Journal of Coal Geology,101, p.36-81. DOI: 10.1016/j.coal.2012.05.011.

Moore, T. A. (2016) Stratified Sampling to Define Levels of Petrographic Variation in Coal Beds, Indonesian Journal on Geoscience 3, pp. 29-51.

Moore, T.A., Ferm, J.C. (1988) A modification of procedures for petrographic analysis of Tertiary Indonesian coals, Journal of South East Asian Earth Science 2, pp. 175-183.

Moore, T.A., Ferm, J.C. (1992) Composition and grain size of an Eocene coal bed in southeastern Kalimantan, Indonesia, International Journal of Coal Geology 21, pp. 1-30.

Moore, T.A., Hilbert, R.E. (1992) Petrographic and anatomical characteristics of plant material from two peat deposits of Holocene and Miocene age, Kalimantan, Indonesia. Review of Palaeobotany and Palynology 72, pp. 199-227.

Paterson, D.W., Bachtiar, A., Bates, J.A., Moon, J.A., Surdam, R.C. (1997) Petroleum system of the Kutei Basin, Kalimantan, Indonesia, Petroleum 


\section{F. ANGGARA et al.}

Systems of SE Asia and Australasia Conference, Jakarta, May 1997, Indonesian Petroleum Association, pp. 709-726.

Satyana, A.H., Nugroho, D., Surantoko, I. (1999) Tectonic controls on the hydrocarbon habitats of the Barito, Kutei, and Tarakan Basins, Eastern Kalimantan, Indonesia: major dissimilarities in adjoining basins, Journal of South East Asian Earth Science 17, pp. 99-122. . 